\title{
TOLERABILITY, ADVERSE EVENTS AND COMPLIANCE TO GLATIRAMER ACETATE IN 28 PATIENTS WITH MULTIPLE SCLEROSIS USING THE DRUG CONTINUOUSLY FOR AT LEAST SIX MONTHS
}

\author{
Ana Patricia Perez Fiore1, Yara Dadalti Fragoso²
}

\begin{abstract}
Aim: To assess tolerability, adverse events and compliance to treatment with glatiramer acetate in multiple sclerosis. Method: Review of patient re co rds and individual interviews. Results: 30 individuals residing in the coastal region of the State of São Paulo who had been in use of glatiramer acetate for at least 6 months were identified. From this group, 28 individuals came to regular consultations and were individually assessed, their complaints being noted down in confidential records. Ten patients reported systemic reactions to the drug. Four of them stopped the medication due to such reactions. Eight patients reported local reactions to the injections. Compliance with injections was achieved, although three patients reported forgetting the injection on a few days. Conclusion: We noticed a higher level of systemic adverse events in our patients than in reports in the literature.
\end{abstract}

KEY WORDS: multiple sclerosis, glatiramer acetate, copaxone.

\begin{abstract}
Tolerabilidade, eventos adversos e aderência ao acetato de glatiramer em 28 pacientes com esclerose múltipla usando a droga continuamente por pelo menos seis meses

RESUMO - Objetivo:Avaliar tolerância, eventos adversos e aderência ao tratamento com acetato de glatiramer em esclerose múltipla. Método: Revisão de prontuários de pacientes e entrevistas individuais. Resulta dos: 30 indivíduos residentes na região do litoral do Estado de São Paulo, que fizeram tratamento com acetato de glatirâmer por pelo menos 6 meses foram identificados. Deste grupo, 28 indivíduos compareceram a consultas re gula res e foram avaliados individualmente, sendo suas queixas anotadas em prontuário confidencial. Dez pacientes relataram reações sistêmicas à droga. Quatro deles suspenderam o tratamento devido às reações. Oito pacientes relataram reação local às injeções. Aderência às injeções foi obtida, e mbora três pacientes admitam ter esquecido a injeção alguns poucos dias. Conclusão: Observamos um índice maior de reações sistêmicas em nossos pacientes do que o relatado na literatura.
\end{abstract}

PALAVRAS-CHAVE: esclerose múltipla, acetato de glatiramer, copaxone.

Glatiramer acetate (Copaxone ${ }^{\circledR}$ ) is a synthetic copolymer composed of four amino acids that modify the inflammation and demyelination of the central nervous system that are characteristic of multiple sclerosis (MS) ${ }^{1}$. The induction of glatiramer acetate-reactive $T$ helper 2 (Th2)-like regulatory suppressive cells and the interference with $\mathrm{T}$ cell a ctivation as an altered peptide ligand seem to be the main mechanisms of action of this dru $\mathrm{g}^{2-4}$. Glatiramer acetate is reported to be well-tolerated ${ }^{1,5,6}$. Glatiramer acetate is not associated with the influenza-like syndrome or neutralizing antibodies that are reported in patients treated with interferonbeta for relapsing - remitting MS (RRMS) ${ }^{1}$. The most commonly re p o rted adverse events have been injection-site reactions and transient post-injection systemic reactions. Both reactions are generally mild and self-limiting, but have been responsible for the majority of withdrawals from treatment (6.5 and $3.5 \%$, respectively) ${ }^{1}$. Daily subcutaneous injections have not yet been reported as a reason for failed compliance with treatment. Lipoatrophy at the injection site has been reported ${ }^{7}$.

Results from the literature are based on clinical trials conducted under ideal situations that may not fully reflect the daily practice of a specialized center ${ }^{8}$. It has been our impression that several MS patients treated with glatiramer acetate in our Re-

CEREM Litoral Paulista, DIR XIX, Department of Health for the State of São Paulo and Department of Neurology, School of Medicine of UNIMES, Santos SP, Brazil: 'BSc, Head Nurse, Lecturer of Nursing School UNIMES; ${ }^{2} \mathrm{MD}, \mathrm{MSc}$, PhD, Lecturer in Neurology, Medical School UNIMES 
ference Center for Multiple Sclerosis (CEREM Litoral Paulista) are discouraged from using the drug due to transient side effects. Despite our endeavors to explain the adverse events to patients, their own private clinicians and neurologists have claimed that such systemic events are "anaphylactic shock" relating to the drug, thus requiring its suspension.

We present our data on 28 patients who have been undergoing treatment with glatiramer acetate for over six months. Tolerability, adverse events and compliance to this treatment are assessed.

\section{METHOD}

CEREM Litoral Paulista is the Reference Center for MS patients residing in the coastal region of the State of São Paulo, Brazil. In Febru a ry 2005, there were 104 patients registered in our center; 30 of them had been und e rgoing treatment with glatiramer acetate for at least six months.

Confidential medical records of all these patients were reviewed, and they were interviewed with the particular purpose of assessing tolerability, adverse events, and compliance with the treatment. Two patients could not be contacted due to telephone number changes, and therefore could not answer particular questions in our assessment. Despite having their data in clinical records, we decided to exclude these two patients from the $g$ roup. Thus, 28 patients were evaluated during the months of January and February 2005.

\section{RESULTS}

The group consisted of 22 women and 6 men, aged 15 to 64 years. Twenty-five patients presented RRMS and three patients presented secondaryprog ressive MS (SPMS) with relapses. Nine women and two men had previously received beta-interferon for MS treatment and did not tolerate the side effects of these drugs. The remaining 17 patients we re receiving glatiramer acetate as their first immunomodulatorytreatment. The period of tre atment with glatiramer acetate ranged from 7 to 24 months (average: 12 months).

The head nurse instructed all patients receiving immunomodulators (glatiramer acetate and beta-interferon) on how to perform the injections. From this group of 28 patients using glatiramer acetate for at least 6 months, 8 re ported local injection-site reactions (itching, swelling, erythema, bruises and/or pain). These patients were invited to performthe injections in our presence and were further instructed on the technique. Characteristically, these patients presented such reactions during the first month of treatment. They all improved and no patient was discontinued from glatiramer acetate treatment due to local injection-site reactions.
Ten patients presented systemic reactions to glatiramer acetate, characterized by flushing, chest pain, palpitations, anxiety, dyspnea and constriction of the throat. Not all symptoms were present in all patients, but in all cases the symptoms were transient, self-limited and required no medical intervention. The symptoms spontaneously resolved after 5 to 25 minutes. Six patients presented only one such episode, while two patients presented two episodes, and two patients had these symptoms on three separate occasions. In all cases, the symptoms only appeared after at least two months of treatment.

All ten patients with systemic reactions were very disturbed by these symptoms, describing the feeling as "near death". Their private clinicians and neurologists urged their patients to seek a change of immunomodulator, since such reactions might have been due to "anaphylactic shock". Two patients who presented the systemic reaction once, and one patient who presented it twice, refused to continue on the medication. They are now undergoing treatment with beta-interferon, as requested by their private neurologists. Another patient, who presented symptoms three times, refuses to take any form of immunomodulatory treatment. The other 6 patients continue using glatiramer acetate to the present date.

Patients were invited to report on possible reasons for the systemic reaction on the particular day it happened. Five patients re ported that they might have performed the injection while the liquid was still too cold, i.e. before it had reached body temperature Two of these patients also reported that they might have perf o rmed the injection too fast. Five other patients could not associate the systemic reaction to any particular occurrence. There were no cases of lipoatrophy at the subcutaneous injection sites.

Two patients presented both local and systemic reactions to glatiramer acetate. Both of them have continued on this treatment.

Compliance with treatment was assessed by asking the patients whether they ever remained without injections, even if only for one day. Three patients admitted to having forgotten to perf o rm the injection at least once. All patients with systemic adverse events to glatiramer acetate had stopped the medication for at least one day, while seeking medical advice. Two patients were instructed by their private neurologist to remain without the injections for at least two weeks, due to pulsotherapy with prednisolone during MS relapses.

Altogether, seven patients were withdrawn from treatment with glatiramer acetate after at least 
six months of continuous use of this drug. Apart from the four patients with systemic reactions, described above, three patients had the treatment changed at the request of their neurologists, due to lack of response to treatment.

\section{DISCUSSION}

The aim of the present work was not to assess the efficacy of glatiramer acetate. It would have been presumptuous to pursue such goal in a small series of patients who have been taking the drug for a relatively short period of time. Rather, our aim was to evaluate the tolerability of this drug among MS patients, in comparison to reports from the literature. Clinical trials are organized under ideal conditions ${ }^{8}$, in which patients are not treated by different neurologists. In our general clinical practice, patients are treated by their private neuro logists and come to the Reference Center for routine assessment. They are registered in the Center at the time of confirmed diagnosis and receive immunomodulators according to a strict protocol from the Brazilian Ministry of Health. Although these patients are free to come for consultations with us, the majority of them continue the treatment with their private doctors and come only for biannual routine evaluation. Relapses, changes in medications, adverse events and dropouts from tre atment are reported to us.

There were relatively few local injection siterelated adverse effects among our group of patients, in relation to reports in the literature ${ }^{1,9-11}$. While up to $50 \%$ of all patients may experience such reactions ${ }^{9}$, in our Reference Center such reactions affected fewer than $30 \%$ of all patients and were resolved by guidance from the head nurse.

Compliance with daily injections was not a major problem, and only a few patients occasionally forgot the injection for one day. However, the suspension of treatment while on pulsotherapy, as prescribed by the private neurologists was unnecessary, according to the guidelines from the Brazilian Committee on Treatment and Research on Multiple Sclerosis (BCTRIMS) ${ }^{12}$. Moreover, the mechanism of action of glatiramer acetate itself may be a contraindication for systematic suspension of this drug ${ }^{13}$.

In our series of patients, the presence of systemic adverse events was higher than in reports in the literature, thus leading to more discontinuation of treatment than seen in clinical trials ${ }^{1,9-11}$. While clinical trials have re ported an average of $10 \%$ of patients presenting systemic reactions over two years, we observed such reactions in $37.5 \%$ of our patients after only six months. Such reactions led $14.2 \%$ of all our patients ( $40 \%$ of those patients with systemic reactions) to drop out from treatment, after six months. The literature reports $3.5 \%$ of $w i-$ thdrawals over two years ${ }^{1}$. There is no evidence of any anaphylactic shock reaction to glatiramer acetate, as claimed by the private neurologists caring for their MS patients.

In conclusion, despite claims of low rates of adverse events with glatiramer acetate, we observed that a number of patients had the treatment discontinued due to systemic reactions. Such reactions seem to be very worrying for patients and their private clinicians and neurologists, and it is necessary to inform them both regarding the frequency of these side effects before initiating treatment with glatiramer acetate. Although re ported to be relatively rare in the literature, we have concluded that in our population these systemic reactions are relatively frequent, even if only one episode is observed during the course of treatment. It is also necessary to inform neurologists working with pulsotherapy during MS relapses that there is no need to interrupt glatiramer acetate for any period of time. As a matter of fact, such interruption may even be deleterious for sustained immunomodulation.

\section{REFERENCES}

1. Simpson D, Noble S, Perry C. Glatiramer acetate: a review of its use in multiple sclerosis. CNS Drugs 2002;16:825-850.

2. Francis DA. Glatiramer acetate (Copaxone). Int J Clin Pract 2001;55:394-398.

3. Putheti P, Soderstrom M. Link H, Huang YM. Effects of glatiramer acetate (Copaxone) on CD4+CD25 high T regulatory cells and their IL-10 production in multiple sclerosis. J Neuroimmunol 2003;144:125-131.

4. Dhib-Jabult S. Glatiramer acetate (Copaxone) therapy for multiple sclerosis. Pharmacol Ther 2003;98:245-255.

5. Ziemssem T, Neuhaus O, Hothfield R. Risk-benefit assessment of glatiramer acetate in multiple sclerosis. Drug Saf 2001;24:979-990.

6. Munari LM, Fillippini G. Lack of evidence for use of glatiramer acetate in multiple sclerosis. Lancet Neurol 2004;3:641.

7. Edgar CM, Brunet DG, Fenton P, McBride EV, Green P. Lipoatrophy in patients with multiple sclerosis on glatiramer acetate. Can J Neurol Sci 2004;31:58-63.

8. Rothwell PM. External validity of randomized clinical trials: "to whom do the results of this trial apply?" Lancet 2005;365:82-93.

9. Munari L, Lovati R, Boiko A. Therapy with glatiramer acetate for multiple sclerosis. The Cochrane Database of Systematic Reviews 2003, Issue 4. Art. No.: CD004678.

10. Fletcher S, Va rdi J, Pollak L, Rabey JM. Comparison of glatiramer acetate (Copaxone) and interferon beta- $1 \mathrm{~b}$ (Betaferon) in multiple sclerosis patients: an open-label 2-year follow-up. J Neurol Sci 2002;197:51-55.

11. Wolinsky JS. Glatiramer acetate for the treatment of multiple sclerosis Expert Opin Pharmacother 2004;5:875-891.

12. Tilbery CP, Moreira MA, Mendes MF, et al. Recomendações quanto ao uso de drogas imunomoduladoras na esclerose múltipla: o consenso do BCTRIMS. Arq Neuropsiquiatr 2000;58:769-776.

13. Vieira PL, Heystek HC, Wormmeester J, Wierenga EA, Kapsenberg ML. Glatiramer acetate (copolymer-1, copaxone) promotes Th2 cell development and increased IL-10 production through modulation of dendritic cells. J Immunol 2003;170:4483-4488. 